\title{
コナヒョウヒダニとヤ゙ケビョウヒダニの 個体群動態に関する比較研究
}

\author{
須藤 千 春* 彭城郁子* 伊藤 秀子** \\ * 名古屋大学医学部㗨動物学教室（开466 名占屋柿昭和区鶴舞町 65） \\ ** 名古屋市衛生研究所（宁467 名古屋市瑞穂区萩山町 1-11）
}

(受領：1990 年 12 月 3 日)

Comparative studies on the population dynamics of house dust mites, Dermatophagoides farinae and D. pteronyssinus (Acari : Pyroglyphidae) in homes in Nagoya Chiharu SUTO, ${ }^{*}$ Ikuko SAKAKI* and Hideko ITO**

* Department of Medical Zoology, Nagoya University School of Medicine, Showa-ku, Nagoya 466, Japan

** Nagoya Municipal Institute of Public Health, Mizuho-ku, Nagoya 467, Japan

\begin{abstract}
Key words : house dust mite, Dermatophagoides pteronyssinus, Dermatophagoides farinae, population dynamics, seasonal fluctuation, population structure.
\end{abstract}

はじめに

室内歴性アレルギー疾患におけるヒョウヒダニ・アレ ルゲンの役割が世界的に明確になってきた (Platts-Mills and Chapman, 1987；WHO, 1988). したがって，ヒョ ウヒダニ類の生態を解明し，より効果的なアレルギー疾 患の予所法を確立することが望まれている。.とくに喘息 の発作溑度とヒョウヒダニ類個体数の増減とは関連する ので (Spieksma and Spieksma-Boezeman, 1967), 個 体数変動とその要因の解析は重要な課題である.

一般的にヤケヒョウヒダニ (Derinatophagoides pteronyssinus, D. p. と略す) はコナヒョウヒダニ（D. farinae, $D . f$.$) よりも湿潤な環境を好むといわれ，西$ 北ヨーロッパや海岸地方の家庭では D. p. が優占し, 北アメリカやヨーロッパの内陸部の家庭では $D . f$. が 優占している (Bronswijk and Sinha, 1971).ところが 日本の一般家庭においては $D . f$. と D.p. が比較的多 数生息しており, その分布, 優占度が家庭により大きく
異なる（大島，1971；高岡ら，1977；彭城ら，1987）。 ま た高温・多湿な夏期に D. f. が多く，乾燥した冬期に D. p. が多いと報告されている（宮本・大内，1976； 高岡ら，1977；高岡・岡田，1984).

室内歴中のヒョウヒダ二類個体数は一般に夏期に最も 多く, 秋から冬にかけて減少し, 厳冬期に最低となり, 春に再び増加する（宮本・大内, 1976 ; Arlian et al., 1982，1983；高岡・岡田，1984）. しかし大島 (1975) お よび高岡ら（1977）は室内塵中のヒョウヒダ二類個体数 に有意な 季節的変動が認められなかったと報告してお り，森谷（1988）は冬期に個体数のピークを示す家庭も あったと述べている：わが国におけるこのようなヒョウ ヒダ二類の生息状況の特徴は, 室内床面に疊を敷くなど の家庭環境の特殊性を反映していると考えられるが，相 互の具体的な関係は明らかではない。

本報では， $D . f$.と $D . p$. の個体群動態および集団 構造の季節的変化に及ぼす部屋の用途や床材などの影響 について比較検討し, 両種の生態学的特性および $D . f$. 
Table 1 Conditions of houses surveyed.

\begin{tabular}{cccccccc}
\hline \hline House & Location & Type & $\begin{array}{c}\text { Age } \\
\text { (years) }\end{array}$ & $\begin{array}{c}\text { No. } \\
\text { rooms/house }\end{array}$ & $\begin{array}{c}\text { Family } \\
\text { size }\end{array}$ & & Floor material \\
\hline A & Urban & Wood & 4 & 5 & 1 & Tatami & Wood \\
B & Urban & Wood & 10 & 5 & 4 & Carpet & Tatami \\
C & Urban & Wood & 38 & 8 & 5 & Wood & Carpet \\
D & Urban & Apartment & 8 & 3 & 4 & Tatami & Tatami \\
E & Rural & Wood & 9 & 4 & 3 & T+C & Tatami \\
F & Urban & Wood & 15 & 8 & 4 & T+C & Wood \\
G & Urban & Wood & 4 & 3 & 4 & Tatami & Tatami \\
H & Rural & Wood & 12 & 3 & 4 & Wood & Tatami \\
I & Urban & Concrete & 5 & 5 & 5 & Carpet & Carpet \\
J & Urban & Apartment & 4 & 3 & 4 & Tatami & Tatami \\
\hline
\end{tabular}

L-room, living room; B-room, bedroom ; T, tatami ; C, carpet.

にみられる休眠（彭城ら，1990；須藤・彭城，1990）の 生態学的意義を明らかにすることを目的とした。このた め冬期の個体群動態にとくに注目した.

\section{材料と方法}

\section{1. 調查対象と調査時期}

名古屋市およびその近郊の一般家庭 10 戸を調查対象 とし，各家庭の居閒および漫室の床面から室内塵を採集 し，ヒョウヒダニ類について調查した． 7 戸には臨床的 にヒョウヒダニ・アレルゲンによると診断された小児喘 息患者（ $3 \sim 10$ 歳, RAST スコア，3〜4）が，1戸 にはアトピー性皮膚炎患者がみられた，家屋の立地条 件，床材の種類などを Table 1 に示した。目常の掃除 にはおもに電気掃除機が使用されており，喘息患児のい る家庭では掃除に努めるように医師から指導されてい た.

調查期間は 1983 年 9 月から 1985 年 6 月までの約 2 年 間で，3カ月に 1 度の割合で調査した. 1983 年 9 月から 1984 年 6 月までの成績を 1983 年度の，1984 年 9 月から 1985 年 6 月までの成績を 1984 年度の結果として 表示し た.

\section{2. 室内塺の採集法およびダニの分離法}

室内塵の採集は各家庭の主婦が手持ちの電気掃除機を 使用して行った．電気掃除機の T型吸引口とホースの連 結部に，掃除機用の紙フィルターで作ったロート状の集 塺袋を挿入し，床面をゆっくり 2 往復させて採塺した (彭城ら，1991). 得られた塵を早急に回収し，ダ二の分㕍 までー $20^{\circ} \mathrm{C}$ に保存した。採集塵の重量は $0.2 \sim 2.2 \mathrm{~g}$ であった。

採集應を科量後, 上部 32 メッシュ,下部 200 メッシュ
の重ね合わせたふるいでよく振とうした，200メッシュ 上の細塵 $0.1 \mathrm{~g}(0.1 \mathrm{~g}$ 以下の場合に は全量を使用し た）から改良飽和食塩水浮遊法（彭城ら，1991）により 全浮遊液，フラスコ壁面洗浄液 および残椬部からダ二 （破損個体を含む）を分離し，ガム・クロラール液に封入 し，生物䫓微鏡下で同定，計数した。 ヒョウヒダ二類は 種別，性別，発育段階別に記録したが，若虫のなかには 生殖突起を明瞭に観察できない個体もあったので，前若 虫と後若虫の区別をせず，単に若虫とした．また後述の ように室内塵試料中の $D . f$. と D.p. の出現頻度が対 数正規分布を示したので，各試料より得られたダ二数を 対数 $\log (X+1)$ に変換して平均值を求め, その值を 自然数に再変換して表示した（Makiya，1976).

\section{結 果}

1. 室内應試料中のヒョウヒダ二類の出現頻度分布型 細塵 $0.1 \mathrm{~g}$ あたりの検出ダニ数は試料により大きな 差 (0〜363 個体) がみられたので，まず各試料中のダ二 の出現頻度分布型について検討した. Fig. 1 は対数正規 確率紙上に $D . f$. および $D . p$. の検出数の累積頻度百 分率を，1983 年度と 1984 年度の成績を合わせて，調査 時期別にプロットしたものである. その結果, 累積頻度 百分率はほぼ直線にのり, 試料中のダ二数は対数正規分 布することが示された．また，D. $f$. と D. p. では調 查時期による検出個体数の増大順序に相違がみられ注目 された。

\section{2. 各家族におけるヒョウヒダニ類の年次的変化}

各家庭において 1983 年度および 1984 年度に検出され た D. $f ., D . p$. の平均個体数と優占度を Table 2 に示 した. 家庭により $D . f ., D . p$. の平均個体数は大きく 


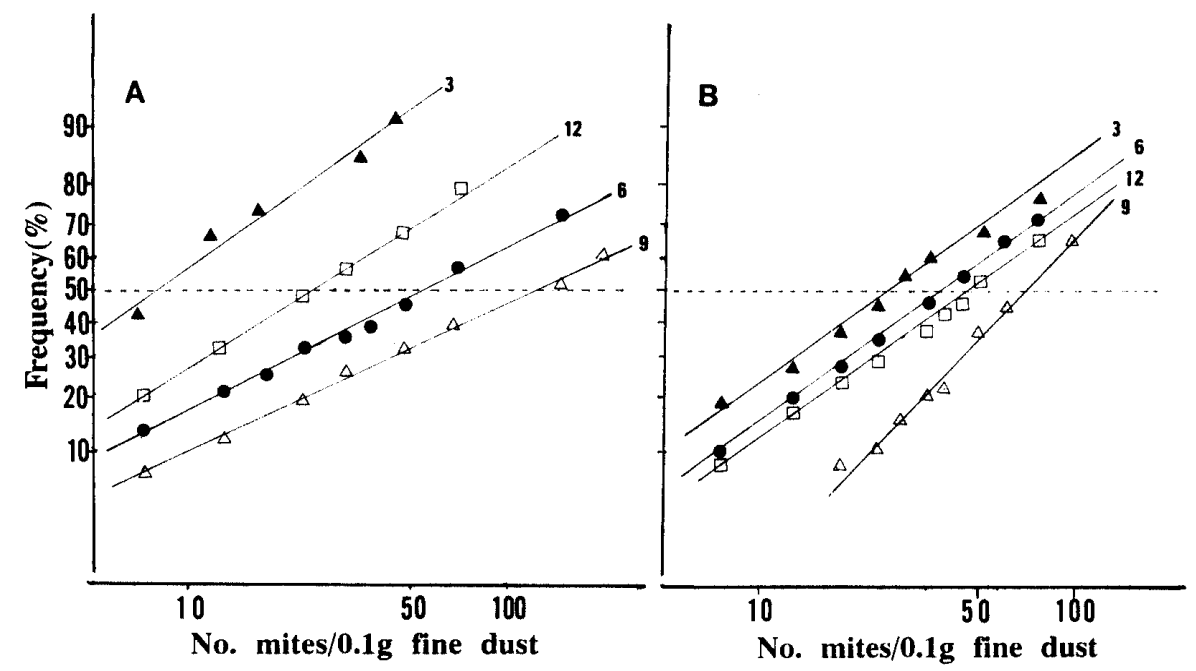

Fig. 1 Frequency distribution of $D$. farinae (A) and D. pteronyssinus (B) in house dust samples collected from living rooms and bedrooms of 10 homes in Nagoya district at about 3 month intervals from September 1983 to June 1985.

$\Delta$, September ; $\square$, December ; $\Delta$, March ; $\bullet$, June.

Table 2 Abundance of the house dust mites in floor dusts collected from 10 homes in Nagoya district, from September 1983 to June 1985.

\begin{tabular}{|c|c|c|c|c|c|c|c|c|}
\hline \multirow{3}{*}{ House } & \multicolumn{4}{|c|}{ Mean No. mites $/ 0.1 \mathrm{~g}$ fine dust } & \multicolumn{4}{|c|}{ Composition percent } \\
\hline & \multicolumn{2}{|c|}{ D. farinae } & \multicolumn{2}{|c|}{ D. pteronyssinus } & \multicolumn{2}{|c|}{ D. farinae } & \multicolumn{2}{|c|}{ D. pteronyssinus } \\
\hline & 1983 & 1984 & 1983 & 1984 & 1983 & 1984 & 1983 & 1984 \\
\hline A & 64.9 & 70.6 & 14.2 & 12.1 & 82.0 & 85.4 & 18.0 & 14.6 \\
\hline B & 43.0 & 44.2 & 32.1 & 42.3 & 57.3 & 51.1 & 42.7 & 48.9 \\
\hline $\mathrm{C}$ & 17.5 & 26.9 & 6.5 & 2.2 & 72.9 & 92.4 & 27.1 & 7.6 \\
\hline $\mathrm{D}$ & 21.3 & 19.9 & 32.2 & 30.7 & 39.8 & 39.3 & 60.2 & 60.7 \\
\hline $\mathrm{E}$ & 9.5 & 13.8 & 20.1 & 26.2 & 32.1 & 34.5 & 67.9 & 65.5 \\
\hline $\mathrm{F}$ & 17.9 & 11.5 & 8.9 & 5.4 & 66.8 & 68.0 & 33.2 & 32.0 \\
\hline $\mathrm{G}$ & 5.0 & 7.6 & 6.5 & 5.4 & 43.5 & 58.5 & 56.5 & 41.5 \\
\hline $\mathrm{H}$ & 9.1 & 3.0 & 14.0 & 13.0 & 39.4 & 18.8 & 60.6 & 81.3 \\
\hline I & 2.4 & 2.0 & 7.9 & 20.7 & 23.8 & 8.8 & 78.2 & 91.2 \\
\hline $\mathrm{J}$ & 1.7 & 3.0 & 30.9 & 41.0 & 5.2 & 6.8 & 94.8 & 93.2 \\
\hline
\end{tabular}

1983, September 1983 to June 1984 ; 1984, September 1984 to June 1985. Spearman's correlation coefficients between the mean mite densities collected in 1983 and 1984 were 0.857 and $0.797(p<0.01)$ for $D$. farinae and $D$. pteronyssinus, respectively. No positive correlation was noted between the mean densities. of $D$. farinae and $D$. pteronyssinus ( $r=0.191$ for $1983, r=0.087$ for 1984$)$.

異なり，D. $f$. の優占が みられた家庭が 3 戸，D. $p$. の優占した家庭が 5 戸，両種がほぼ同数の家庭は 2 戸で あった．各家庭における 1983 年度と 1984 年度の平均検 出数を Spearman の順位相関法により検討した結果, D. $f$. では相関係数 $r=0.857, D . p$. では $r=0.797$ と，両種ともに高い相関 $(p<0.01)$ を示した. しかし $D . f$. と $D . p$. 間では 1983 年度 $r=0.191,1984$ 年 度 $r=0.087$ で, 有意な相関は認められなかった（ $p>$
$0.05)$.

3. 各家庭におけるヒョウヒダニ類の季節变功

Fig. 2 に各家庭における $D . f$. と $D . p$. の季節変 動を示した． D. $f$. についてみると，検出個体数が比較 的多数であった $\mathrm{A} \sim \mathrm{G}$ の家庭では夏期に多く，冬期に 減少しておおむね規則的な季節変動がみられた。しかし 検出個体数の少なかった $\mathrm{H} \sim \mathrm{J}$ の家庭では明らかな季 節変動を認めなかった. いっぽう，D.p.では $\mathrm{A}, \mathrm{B} の$ 


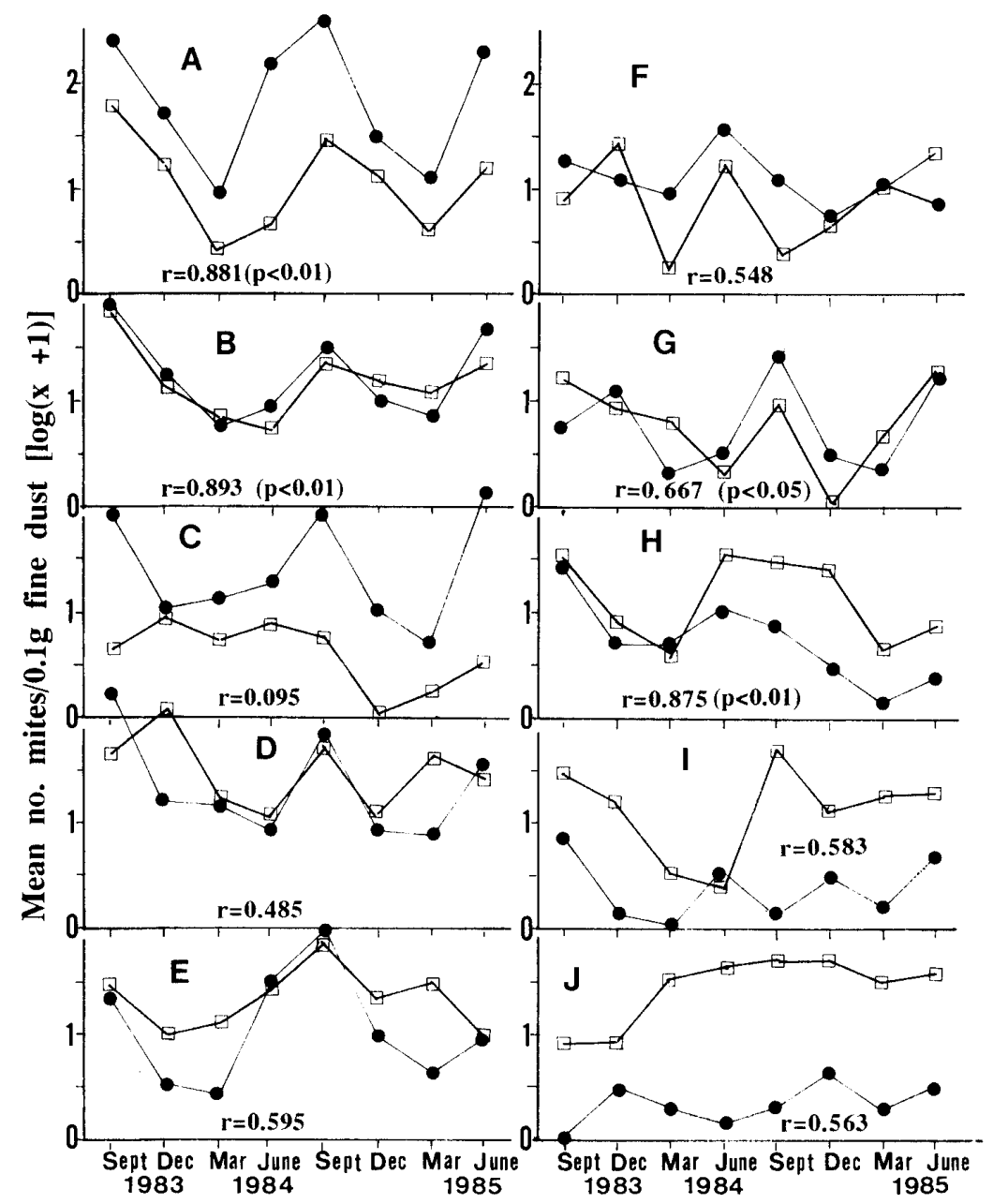

Fig. 2 Seasonal changes in population sizes of $D$. farinae (๑) and D. pteronyssinus ( $\square$ ) in floor dusts collected from living rooms and bedrooms.

$r$, Spearman's correlation coefficient.

ように $D . f$. と同様な変動を示す家庭もみられたが， C〜I では 12 月あるいは 3 月にも比較的多数の個体が検 出され，Jでは 1983 年 3 月から 1985 年 6 月までの検出 個体数がほぼ一定で，D.p. の季節変動は家庭によって 大きく相違することが示された．各家庭における D. $f$. と D. p. の季節変動の相関を検討した結果, $\mathrm{A}, \mathrm{B}, \mathrm{H}$ $(p<0.01)$ および $\mathrm{G}(0.01<p<0.05)$ の家庭で有意な 相関が認められたのみであった。

4. 部屋の用途および床材別にみたヒョウヒダニ類の 季節変動

$D . f$. の居間および蔓室における季節変動を, 床材別 にFig. 3 に図示した。居間, 寝室のいずれの床面でも 規則的な季節変動がみられ，検出数は 9 月に多く，12月 に減少し，3月に最低になり，6月に再び増加した. 板 張りの寝室に拉いて夏期と冬期の個体数に大きな差がみ られたことが注目される。

D. p. の居間および梫室における季節変動を Fig. 4
に床材別に示した．カーペット敷き居閒のように D. $f$. とほぼ同様な季節変動を示す部屋もあったが，畳敷き居 間などでは 12 月にも比較的多数の個体が検出された. た畳敷き寝室では冬期にも夏期とほぼ同数の個体が検出 され，有意な季節変動は認められなかった. D. f. (Fig. 3）と D.p. (Fig. 4) とを比較すると，D.p. は畳敷き の居間，寝室，およびカーペット敷き居間で優占し， $D$. $f$. は板張り寝室で優占する傾向がみられた.

Fig. 5 には，比較のため，畳敷きの居閒および僰室に おける $D . f$. と $D . p$. の季節変動を 1983 年度と 1984 年度の成績を平均して示した．D. $f$. は居間，漫室とも に規則的な季節変動を示したのに対して，D.p.では 12 月および 3 月の冬期個体群において $D . f$. よりも有意 に多数を占め，かつ寝室では年間を通じて比較的安定し た検出数を示した. 


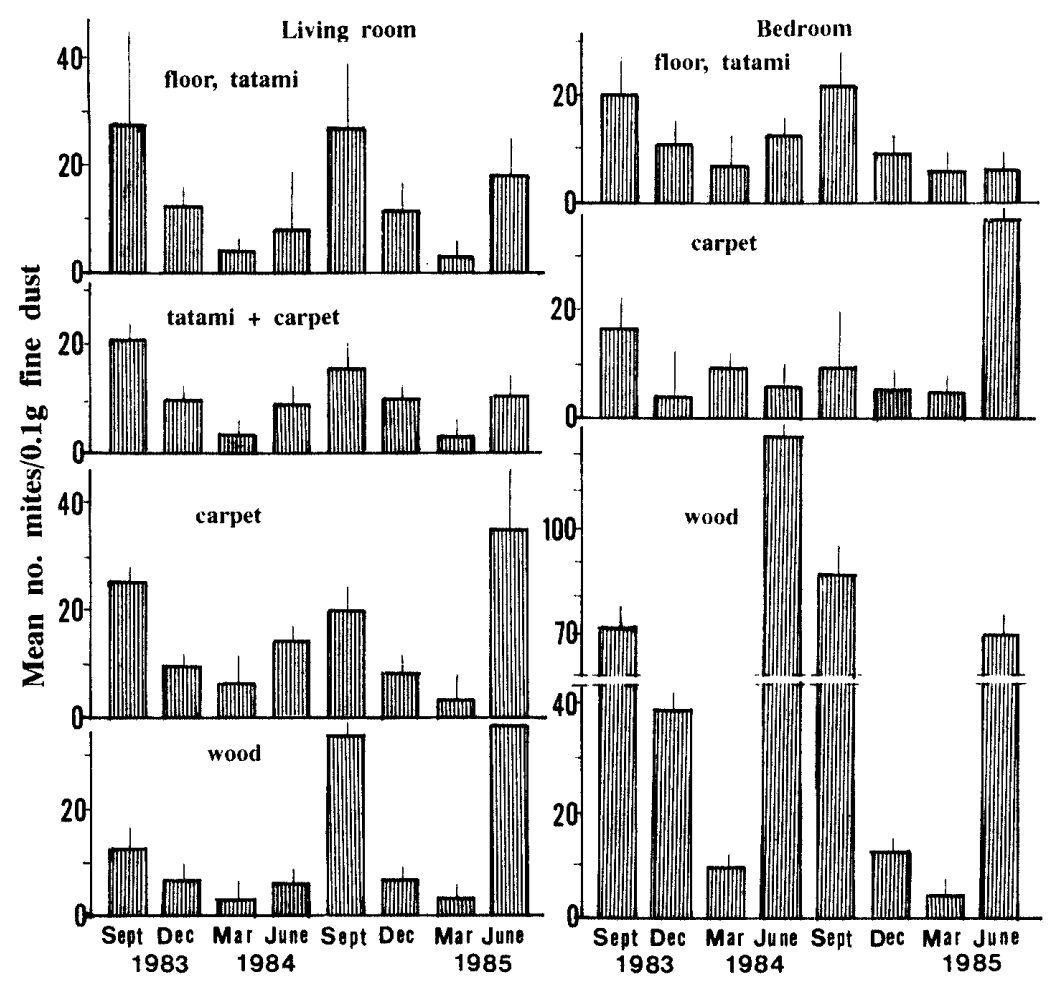

Fig. 3 Seasonal changes in population sizes of $D$. farinae in floor dusts collected from living rooms (left) and bedrooms (right).

Vertical bar, standard deviation of a mean.
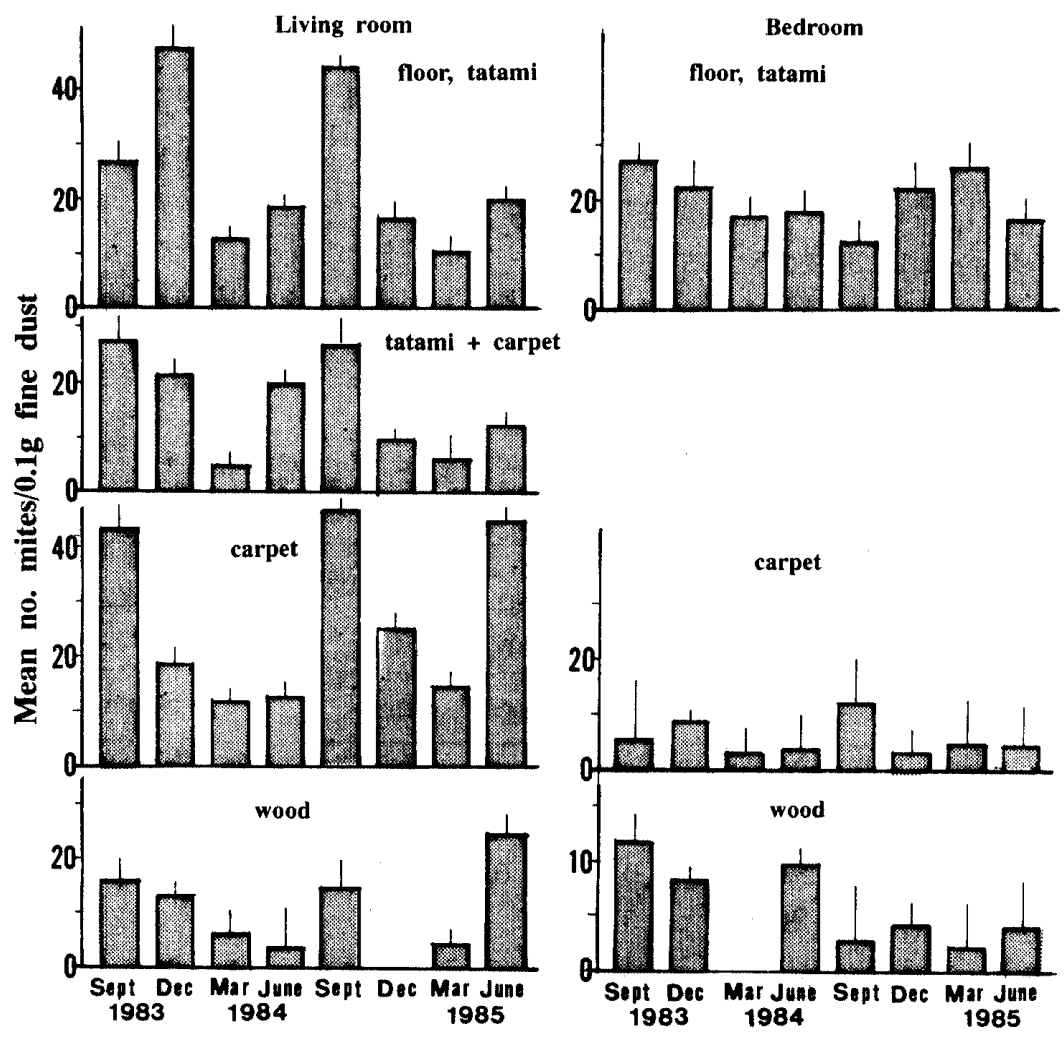

Fig. 4 Seasonal changes in population sizes of $D$. pteronyssinus in floor dusts collected from living rooms (left) and bedrooms (right).

Vertical bar, standard deviation of a mean. 


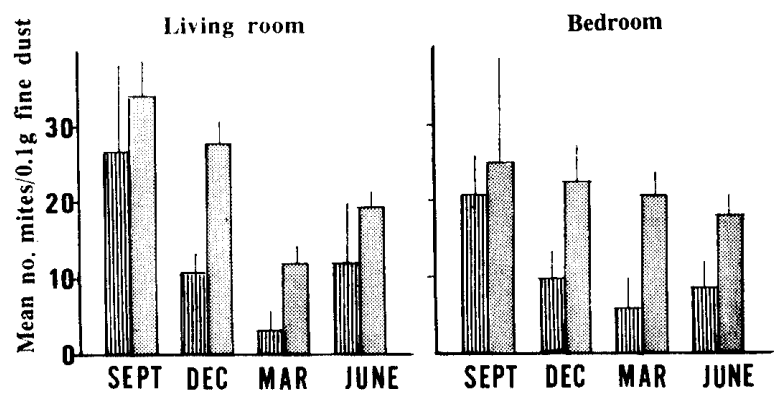

Fig. 5 Comparison of seasonal changes in population sizes of $D$. farinae and $D$. pteronyssinus in floor dusts collected from living rooms (left) and bedrooms (right) with tatami floors.

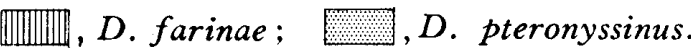

Vertical bar, standard deviation of a mean.

\section{5. 部屋別, 床材別にみたヒョウヒダニ類の集団構造 の季節的変化}

居閒および寝室における $D . f$. と $D . p$. の集団構造 の季節的変化を，1983 年度と 1984 年度の結果を平均し て Table 3 に示した. D. f. では集団構造に季節的変 化がみられ，多数の個体が検出された 9 月には雌・雄成 虫の比はほぼ $1 ： 1$ であった。若虫の割合は雌・雄成虫 より低率であったが，12月および 3 月には雄成虫とほ ぼ同率あるいはそれよりも高くなり，6月には再び低下 する傾向がみられた。

これに対して，D.p. の集団構造には顕著な変化がみ られなかった. すなわち 9 月の個体群で雌・雄成虫の比 はほぼ 1：1で，若虫の割合は 13.3 14.5\%にすぎな かった. 冬期個体群において若虫の割合はやや高まった ものの，雌・雄成虫の約 $1 / 2$ にとどまった．集団構造の
衛 生 動 物

李節的変化が $D . f$. と $D . p$. で異なることが示唆され たので，さらに部屋別，床材別に検討した．

$D . f$. の居間および演室に㧍ける集団構造の季節的変 化を床材別に Fig. 6 と 7 に示した. 夏期個体群では, 上記のように雌・雄成蜘が若虫数にまさっていたが， 冬期個体群では若虫数が雌・雄成虫数とほぼ同数あるい はそれらよりも多くなり，若虫の相対的増加が部屋ある いは床材に関係なく示された。 また冬期個体群では全体 的に雌成蜘が 雄成虫数よりも多くなる傾向がみられ た.

D. p. では畺敷き寝室を除き冬期個体群における若虫 の割合がやや減少したことが特徴的であった（Fig. 8, 9).とくに板張りの居問，侵室およびカーペット敷き寝 室では減少した．畳敷き寝室では個体数のみならず集団 構造も年間を通じてほぼ一定であった（Fig. 9).

\section{6. 部屋数および家族数と優占度との関係}

Fig. 10 は両対数グラフの横軸に各家庭の部屋数を家 族数で割った值をとり，D.p. の優占度（Table 2）を プロットしたものである. 家族数に比べて部屋数の少な 、家庭ほど高い D. p. 優占度を示した。

\section{考察}

\section{1. 各家庭におけるヒョウヒダニ類の生息状況}

1983 年度と 1984 年度に検出された $D . f$. と $D . p$. の平均個体数に相関がみられたことは, ヒョウヒダ二類 の生息している微小環境あるいは室内塵生態系が比較的 安定していることを示唆している.しかし類似の生態的 地位をもつ D. f. と D.p. の個体数には相関がみられ ず，季節変動も家庭間および種間で大きく相違した。

このような $D . f . と D . p$. の生息状況の相違は好適

Table 3 Seasonal changes in population structure of $D$. farinae and D. pteronyssinus in floor dusts collected from living rooms and bedroons.

\begin{tabular}{|c|c|c|c|c|c|c|c|c|c|}
\hline \multicolumn{2}{|l|}{ Mite } & \multicolumn{8}{|c|}{ Percent of mites } \\
\hline \multirow{2}{*}{ Species } & \multirow{2}{*}{$\begin{array}{l}\text { Sex and } \\
\text { stage }\end{array}$} & \multicolumn{4}{|c|}{ Living room } & \multicolumn{4}{|c|}{ Bedroom } \\
\hline & & Sept. & Dec. & Mar. & Jun. & Sept. & Dec. & Mar. & Jun. \\
\hline \multirow[t]{4}{*}{ D. farinae } & Male & 34.4 & 26.9 & 34.7 & 39.1 & 36.8 & 28.0 & 21.0 & 31.9 \\
\hline & Female & 35.6 & 37.7 & 32.8 & 35.8 & 37.2 & 40.8 & 41.2 & 53.8 \\
\hline & Nymph & 26.9 & 31.0 & 32.6 & 20.9 & 22.8 & 29.0 & 33.4 & 13.5 \\
\hline & Larva & 3.0 & 4.5 & 0 & 4.8 & 3.2 & 2.3 & 4.2 & 0.8 \\
\hline \multirow[t]{4}{*}{ D. pteronyssinus } & Male & 42.3 & 36.6 & 34.2 & 37.6 & 42.0 & 41.5 & 42.0 & 38.7 \\
\hline & Female & 42.2 & 45.0 & 42.8 & 52.2 & 41.2 & 41.0 & 40.8 & 49.4 \\
\hline & Nymph & 14.5 & 17.3 & 21.9 & 10.1 & 13.3 & 17.5 & 17.2 & 11.9 \\
\hline & Larva & 0.9 & 0 & 0 & 0 & 3.5 & 0 & 0 & 0 \\
\hline
\end{tabular}

Mite surveys were undertaken at about 3 month intervals from September 1983 to June 1985. 


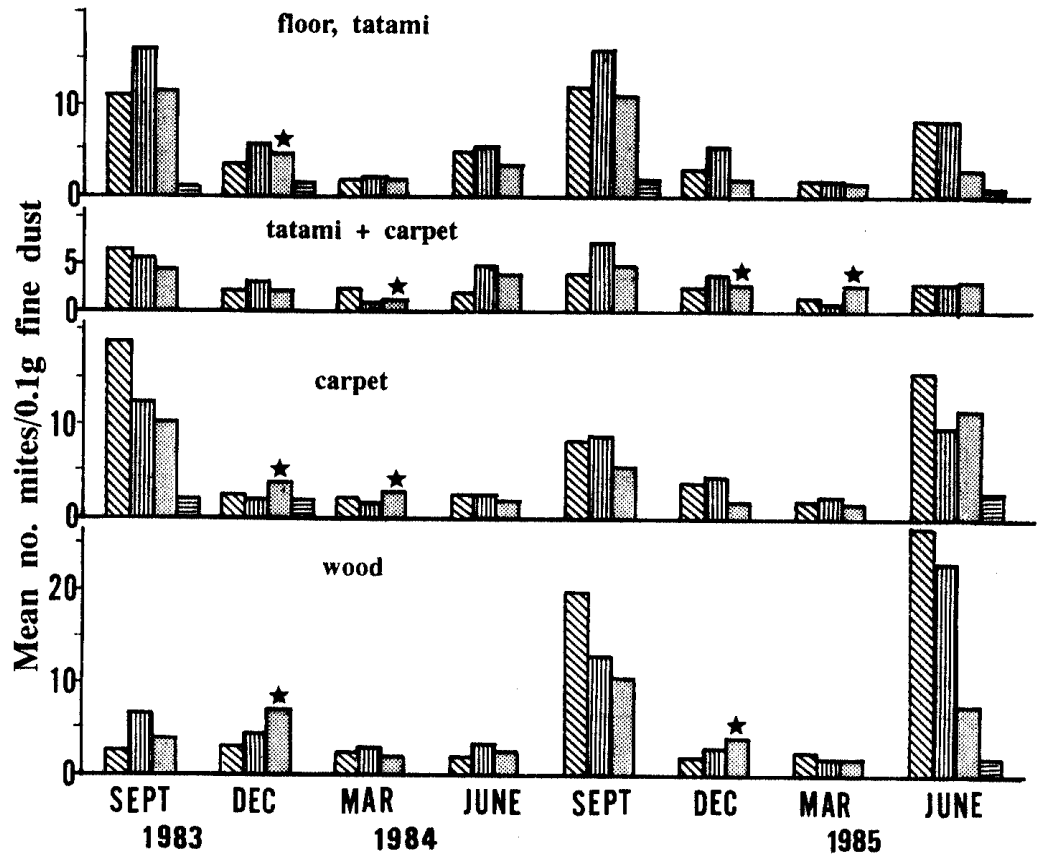

Fig. 6 Seasonal changes in population structure of $D$. farinae in floor dusts collected from living rooms.

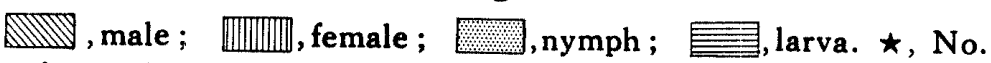
of nymphs $>$ No. of males or females in winter populations.

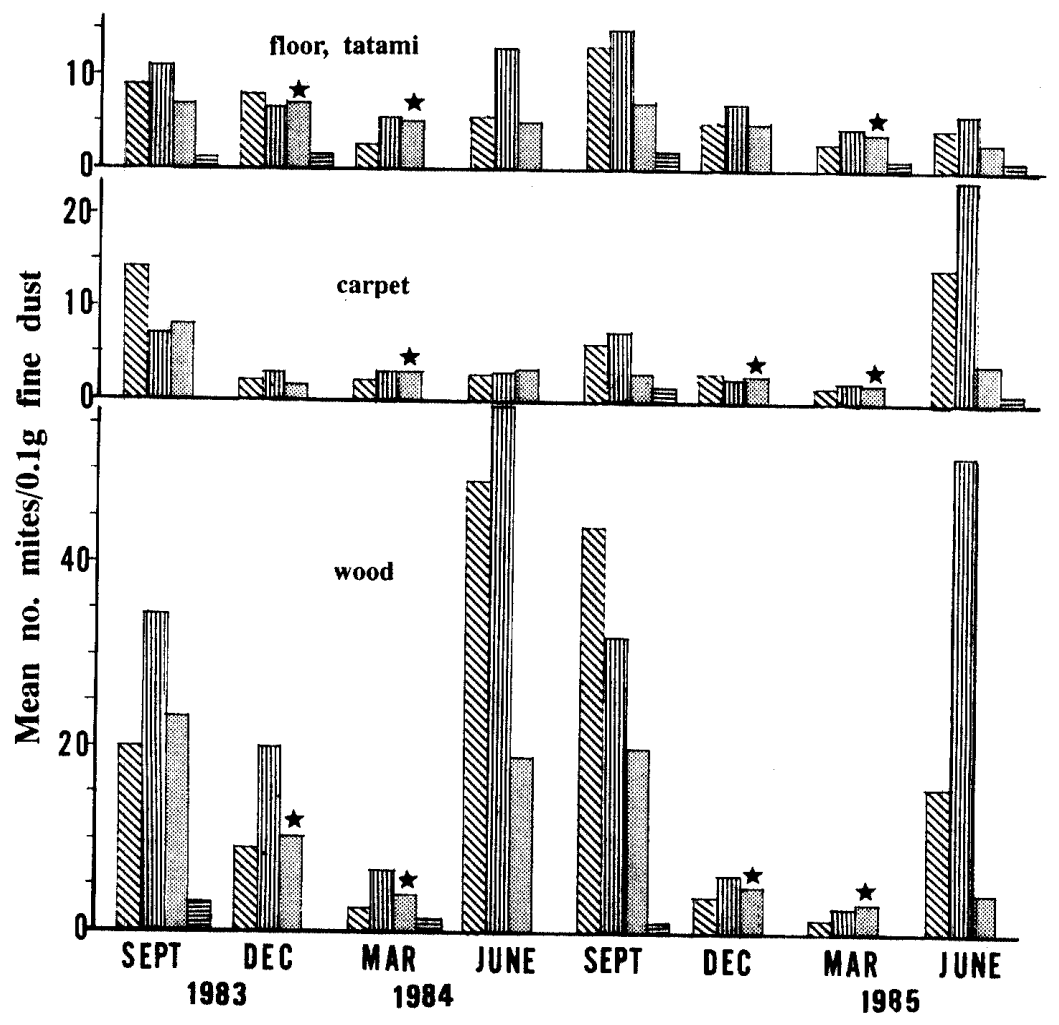

Fig. 7 Seasonal changes in population structure of $D$. farinae in floor dusts collected from bedrooms.

$\mathbb{1}$, male; of nymphs $>$ No. of males or females in winter populations. 


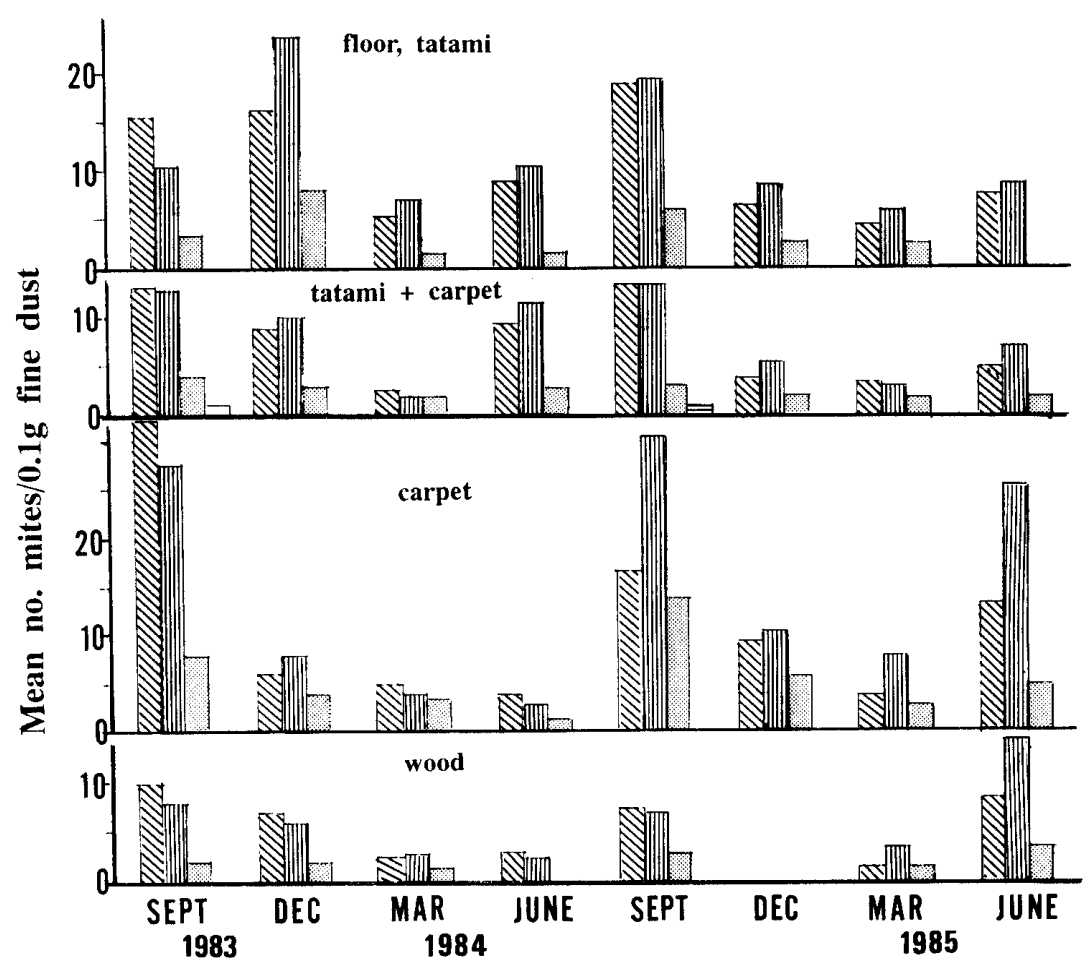

Fig. 8 Seasonal changes in population structure of $D$. pteronyssinus in floor dusts collected from living rooms.

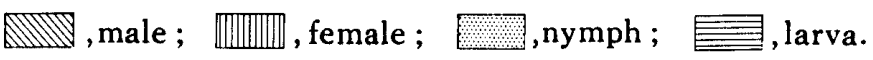

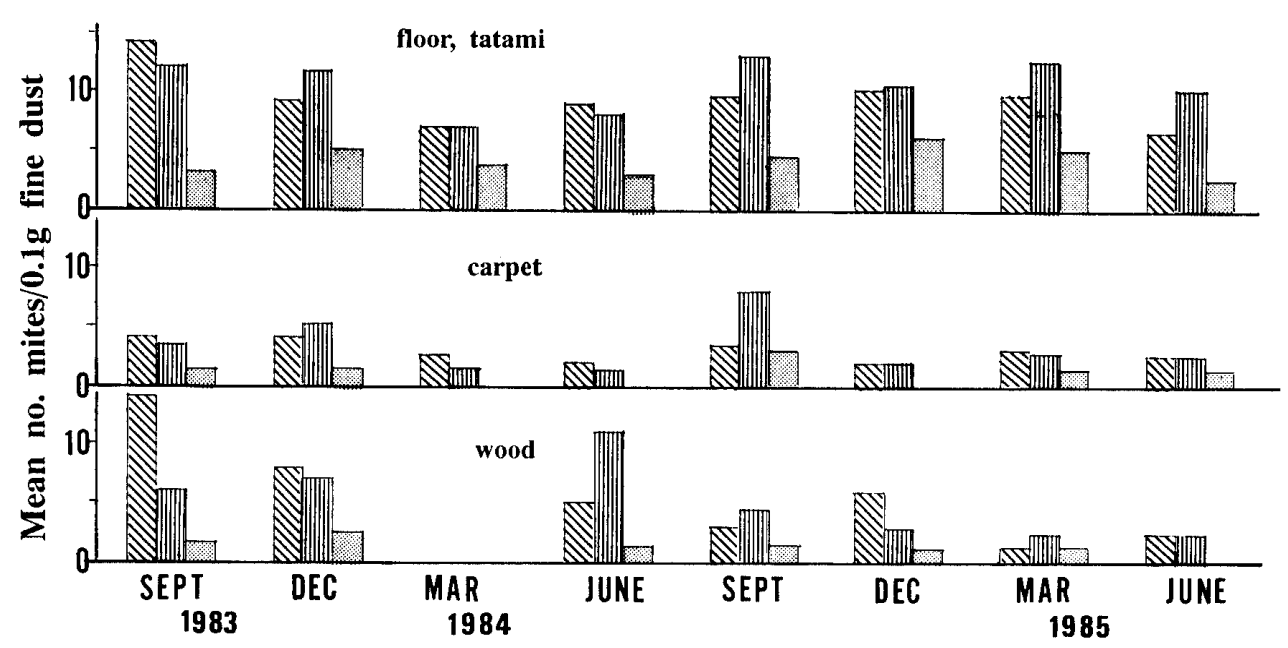

Fig. 9 Seasonal changes in population structure of $D$. pteronyssinus in floor dusts collected from bedrooms.

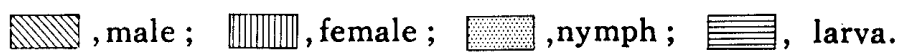

湿度の差によると考えられている。すなわち，大島ら (1972)拉よび大島（1975）渭の含水率と室内塵ダニ数 との関係を検討し，D.f. は高湿度を，D.p. は低湿度 を好むと報告した，この見解は宮本・大内 (1976), 高岡 ら（1977）によって支持されており，本報でも乾燥した 12 月あるいは 3 月に $D . f$. 数よりも D. p. 数の多い 家庭が多くみられた。しかし一般的には D.f.は $D . p$. より耐乾性であるので（Arlian, 1975；Brandt and
Arlian, 1976; Arlian and Veselica, 1981; 松本ら, 1986)，各家庭に括ける上記の D. $f$. と D.p. の生息状 況の相違を湿度の相違のみによって説明することは不可 能のように思われる。

西北ヨーロッパや北アメリカでは，ヒョウヒダニ類の 個体群増殖に対する最も重要な制限要因は相対湿度であ り，個体数は乾燥した冬期（暖房期）に最少になると報 告されている (Spieksma and Spieksma-Boezeman, 


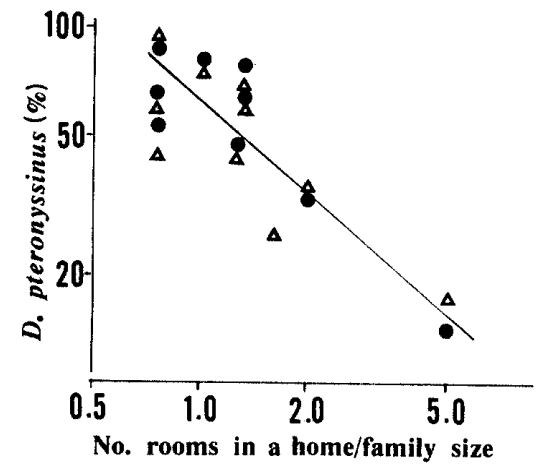

Fig. 10 Relationship between the dominance of $D$ pteronyssinus and the ratio of the number of rooms in a home to the family size.

$\triangle$, September 1983 to June1984;

-, September 1984 to June 1985.

1967 ; Bronswijk, 1973; Dusbábek, 1975; Arlian et al., 1982). 日本の家庭内でも相対湿度は季節的にか なり変動し, $7 \sim 8$ 月には 70 80\% $\mathrm{RH}$ と高く, ヒョウ ヒダ二類の発育・繁殖に適した湿度であるが, その後徐 徐に 減少し，2３月には 臨界平衡湿度以下の 40 60 \% RH になり（大島ら，1972; 宫本・大内, 1976), 生 存・発育に適さなくなる：しかし，冬期の調查成績をみ ると，耐乾性の低いD.p.がかなり多数検出され，有意 な季節変動のみられない家庭もあった，同様な結果が大 島 (1975), 宮本 -大内 (1976), 高岡ら (1977), 高岡・ 岡田（1984）などによっても報告されていることから， 日本の家庭内には乾燥した冬期に，D. $f$.よりも耐乾性 の低い D.p. の生存に適した微小環境の存在する可能 性が示唆される。

2. ヒョウヒダニ類の季節变動に及ぼす部犀の用途お よび床材の影喆

D. p. の季節変動は部屋および床材の相違により異な り，環境要因が大きく影響していると考えられた，とく に疊敷き度室では夏期と冬期の個体数に有意な差がみら れず注目された，演室や演具には人体から蒸散した水分 および落屑物が多く，D.p.の生存に適した微小環境が 存在していると考えられている (Sesay and Dobson, 1972；Bronswijk, 1973；Dusbábek, 1975). また稲 㩰を基材とする畳は保湿性が高く，湿度の緩衝作用を有 すると考えられることから，盢敷き㭡室には D.p.の 生存に適した微小環境が冬期でも存続していると推察さ れる. 逆に板張りの部屋などでは床面の吸湿性, 保湿性 が低く，冬期に乾燥のために D. p. 数が著しく減少した と考えられる。
いっぽう，同じ部屋の櫪中から検出された $D . f$. で は，冬期に 個体数が減少し 規則的な 季節変動がみられ た. D.f.は D.p.よりも一般的に耐乾性であることか ら，冬期における $D . f$. 個体数の減少を生息環境の湿度 低下だけから説明することはできない，この結果はむし ろ, D. f. と D. p. の生態学的特性あるいは越冬生態が 大きく異なることを示唆している.

\section{3. ヒョウヒダ二類の集団權造の季節的变化}

D. p. では，どの部屋でも季節による集団構造に影著 な変化がみられず，とくに睤教き撮室では個体数のみな らず集団構造も夏期と冬期で類似していた。このことか ら，家庭内に寝室として使用する 部屋の割合が高けれ ば，そのような家庭では夏期と冬期で個体数の増減があ まりなく，D.p. が D. f. に優占すると推測されたの で, 部屋数と家族数の比と D. p. 優占度との関係を検討 した.

部屋数と家族数の比が低、家庭では，居間も寝室とし て使用している可能性が高く，また調理，入浴などの生 活活動および人体から蒸散する水分量が多く，D.p.の 生存に適した湿潤な微小環境が存続しているため，高い D.p. 優占度を示したと考察される. Oshima (1967) が 冬期に $2 \mathrm{DK}$ の高層集合住宅で調査し，D. p. の優占 をみていることはこの仮説と矛盾しないが，この説の当 否はさらに多数の調查によって検証する必要があろう。

いっぽう，D. $f$. の集団構造は季節的に変化し，冬期 個体群における若虫の相対的増加が特徴的である．同様 な結果は Dusbábek (1975)および Arlian et al.(1983) などによっても示され，とくに Dusbábek (1975) は前 若虫の割合が 10〜 4月に 50〜 70\%に達すると 報告して いる.

ヒョウヒダニ類の雄成虫は雌成虫よりも耐乾性が低い ことが示されており，雄成虫の体長が雌成虫よりも小さ く，体表面積と体容積の比が大きいことによると説明さ れている (Arlian, 1975; Brandt and Arlian, 1976). この考え方に従えば，成虫よりも体長の小さい若虫は耐 乾性が低く，冬期に成虫よりも減少すると考えられる. しかし D. $f$. の冬期個体群では若虫の相対的増加がみ られ，体表面積比に基づく耐乾性の高低のみによっては 説明できないことが示された．このことから逆説的に， $D . f$. 冬期個体群には酎乾性を獲得した若虫が存在して いると推測される。

4. コナヒョウヒダニ休眠若虫の出現とその生態学的 意燨

実験室内飼育中の $D . f$. および $D . p$. の個体群密度 が増大すると数力月間も脱皮せず，発育を休止する前若 虫（休止若虫と略す）が出現する（Ellingsen, 1975; 
Wharton, 1976). $D f$. 休止若虫は水分透過性が実際上 ゼロに近く，耐乾性であり（Ellingsen，1975)，発育休 止はその誘導，持続，終結などに関与する要因からみて 休眠とみなせる現象であると報告されている（彭城ら， 1990 ; 須藤・彭城，1990). また $D . f$. を主とする個体 群において，4〜5月の個体群増殖の初期に後若虫数が 急激に増加することが見いだされており（Arlian et al. 1983)，室温下で越冬した $D . f$. 休止若虫は，休止した 時期にかかわらず $4 \sim 5$ 月に一斉に脱皮・発育し，個 体群増殖を 温・湿度などの 季節的変化に 同調，調節さ せる機能を有することが示唆されている（彭城・須藤， 1991).

いっぽう，本研究により $D . f$. の個体数は規則的に 季節変動し，冬期に若虫数が相対的に増加することが示 された.このような $D . f$.の個体群動態上の特性には 上記の休止若虫の出現が関係していると考察される。す なわち，D.f.の休止若虫は休眠と同様の生態学的意義 (Tauber and Tauber, 1976) をもつ適応型であり，個 体群動態に重要な役割を果たしていると考えられる.

いっぽう，D.p. では休止若虫が出現しにくいことが 報告されている。松本ら（1986）は，低湿度条件下で $D$ $f$. では延長型（休止）若虫の出現頻度が高まるが，D. p. では死亡率が高まり，延長型若虫は出現しないと報 告している。 また Dusbábek（1979）はわれわれと同様 に，D.p. 個体群では若虫の割合が年閒を通じて成虫よ りも低く, 集団構造に季節的変化がみられないと報告し ている．すなわち，D.p. では休止若虫が出現しにくい ため，夏期と 冬期の 個体群間に 集団構造の 変化が少な く，個体群動態が環境要因の影響を受けやすいと考察さ れる。

以上から，D.f. と D. p. の個体群動態の相違は休 眠性の差異によるものと推察され，わが国の居住環境の 特殊性と関連して，ヒョウヒダ二類の生息状況の特徴の 原因になっていると考察される。したがって，わが国に おける室内塺性アレルギー対策には，ヒョウヒダニ類の 生態学的特性と居住環境の特殊性が，とくに考慮されな ければならないと考える。

\section{まとめ}

1983 年 9 月から 1985 年 6 月まで 3 カ月ごとに，名古 屋市とその近郊の一般家庭 10 戸の居間と葠室における コナヒョウヒダニ $(D . f$.$) とヤケヒョウヒダニ (D.p.)$ の生息状況を調查し，比較検討した。

1）優占種は家庭により異なったが，各家庭における D. $f ., D . p$. の平均検出個体数は年度閒では相関した. しかし，雨種間の生息状況には相関がみられなかった。
2） D. $f$. は夏期に多く冬期に減少し，おおむね規則 的な季節変動を示したが， D. p. では，12月あるいは 3 月に比較的多数の個体が検出された家庭および明瞭な 季節変動のみられない家庭があった。

3） D. f. は部屋の用途や床材の相違に関係なく規則 的な季節変動を示した．D.p. は部屋の用途および床材 の相違により季節変動が異なり，とくに畳敷き寝室では 有意な季節変動を認めなかった.

4） D. $f$. では夏期と冬期で集団構造が変化し，冬期 に若虫が相対的に増加した．D.p. では夏期と冬期の集 団構造に顕著な変化がみられなかった。

5）部屋数に比べて家族数の多い家庭ほど高い D. $p$. 優占度を示した。

6）以上の結果について室内の環境要因，種別の耐乾 性および休眠性の有無などの観点から比較検討した。

本研究にさいしてご指導，ご鞭撻くださり，本稿をご 校閲いただいた熊田信夫名古屋大学名誉教授に深謝いた します。また調查にご協力くださった道端正孝医師およ び室内塵の採取に当たられた各位に憬くお礼申し上げま す.

\section{引用文献}

Arlian, L. G. (1975): Dehydration and survival of the European house dust mites, Dermatophagoides pteronyssinus. J. Med. Entomol., 12 : 432-442.

Arlian, L. G., I. L. Bernstein and J. S. Gallagher (1982): The prevalence of house dust mites, Dermatophagoides spp. and associated environmental conditions in homes in Ohio. J. Allergy Clin. Immunol., 69 : 527-532.

Arlian, L. G. and M. Veselica (1981): Reevaluation of the humidity requirements of the house dust mite, Dermatophagoides farinae (Acari : Pyroglyphidae). J. Med. Entomol., $18: 351-352$.

Arlian, L. G., P. L. Woodford, I. L. Bernstein and J. S. Gallagher (1983) : Seasonal population structure of house dust mites, Dermato. phagoides spp. (Acari: Pyroglyphidae). J. Med. Entomol., 20 : 99-102.

Brandt, R. L. and L. G. Arlian (1976): Mortality of house dust mites, Dermatophagoides farinae and $D$. pteronyssinus exposed to dehydrating conditions or selected pesticides. $J$. Med. Entomol., 13 : 327-331.

Bronswijk, J. E. M. H. van (1973) : Dermatophagoides pteronyssinus (Trouessart, 1897) in mattress and floor dust in a temperate climate (Acari : Pyroglyphidae). J. Med. Entomol., 
$10: 63-70$.

Bronswijk, J. E. M. H. van and R. N. Sinha (1971): Pyroglyphid mites (Acari) and house dust allergy. J. Allergy, $47: 31-52$.

Dusbábek, F. (1975) : Population structure and dynamics of house dust mite, Dermatophagoides farinae (Acari: Pyroglyphidae) in Czechoslovakia. Folia Parasitol., 22 : 219-231.

Dusbábek, F. (1979): Dynamics and structure of mixed populations of Dermatophagoides $\mathrm{fa}$ rinae and $D$. pteronyssinus. In: Recent $A d$. vances in Acarology, II (ed., Rodriguez, J. R.), pp. 173-177, Academic Press, New York.

Ellingsen, I. J. (1975) : Permeability to water in different adaptive phases of the same instar in the American house-dust mite. Acarologia, $17: 734-744$.

Makiya, K. (1976): Some considerations on the distribution pattern of mosquito Aedes albopictus (Skuse) and practical usefulness of the $\log (x+1)$ transformation for the field collection data. Jpn. J. Sanit. Zool., 27 : 399-404.

松本克彦，岡本雅子，和田芳武 (1986)：コナヒョ ウレダニ，ヤケヒョウヒダニの生活史におよぼす 湿度の影響. 街生動物, 37:79-90.

宮本詢子，大内忠行 (1976) : 新築家屋, 一般家庭 での室内塵ダ二類の季節変動について，衛生動 物, $27: 251-259$.

森谷清樹 (1988) : 家屋害虫 2.（日本家屋害虫学 会編），室内に生息するダ二類（I～III），pp. 273-301, 井上書店, 東京.

Oshima, S. (1967) : Studies on the genus Dermatophagoides (Psoroptidae : Acarina) as floor mites, with special reference to the medical importance. Jpn. J. Sanit. Zool., $18: 213-$ 215.

大島司郎 (1971) : 衛生動物学の進步 第 1 集（佳 々 学編), 室内塵とダ二, pp. 203-223, 学術出 版会, 東京.

大島司郎 (1975) : 室内塵性ダ二の季節的変動とそ の変動要因. 小览内科 外科, $7: 461-468$.

大島司郎，中村 譲，杉田和子，米山悦夫，北爪 稳，吉永洋治 (1972)：タタミの水分とダ二の発 生との関係，とくに駆除への応用. 横浜衛研年報, $11: 62-69$.

Platts-Mills, T. A. E. and M. D. Chapman (1987): Dust mites: Immunology, allergic disease, and environmental control. J. Allergy Clin. Immunol., $80: 477-500$.

彭城郁子，須藤千春 (1991)：コナヒョウヒダ二若 虫の長期発育休止（休眠）の室温における終結時 期について。衛生動物, 42: 93-97.

彭城郁子，伊藤秀子，熊田信夫（1987）：名古屋市 およびその近郊家屋における室内塺中のダ二発生 消長について．ペストロジー研究会誌， $2: 16$ 18.

彭城郁子，伊藤秀子，須藤干春（1991）：飽和食塩水
浮遊法の改良による室内麼中のダ二検出につい て。衛生動物, 42:43-46.

彭城郁子, 須藤千春, 伊藤秀子 (1990) : コナヒョウ ヒダ二若虫における発育休止の出現および終了に ついて。衛生動物，41:227-234.

Sesay, H. R. and R. M. Dobson (1972): Studies on mite fauna of house dust in Scotland with special reference to that of bedding. Acarologia, 14 : 384-392.

Spieksma, F. Th. M. and M. I. A. SpieksmaBoezeman (1967): The mite fauna of house dust with particular reference to the house-dust mite Dermatophagoides pteronyssinus (Trouessart, 1897) (Psoroptidae: Sarcoptiformes). Acarologia, 9 : 226-241.

須藤千春, 彭城郁子 (1990): コナヒョウヒダ二前 若虫における長期発育休止（休眠）の誘導，維 持, 終結に関与する原因について。衛生動物，41： 301-307.

高岡正敏, 石井 明, 椛沢靖弘, 大内忠行 (1977)： 小児喘息患児の屋内麾中のダ二相について，衛生 動物， $28: 237-244$.

高岡正敏，岡田正次郎（1984）：埼玉県下に招ける 家屋内ダニ相の生態学的研究. 室内塵中ダ二類の 季節消長. 衛生動物, 35: 129-137.

Tauber, M. J. and C. A. Tauber (1976) : Insect seasonality: Diapause maintenance, termination and postdiapause development. Annu. Rev. Entomol., 21 : 81-107.

Wharton, G. W. (1976): House dust mites. J. Med. Entomol., 12 : 577-621.

WHO (1988): Dust mite allergens and asthma. Bull. W.H.O., 66 : 769-780.

\section{Summary}

Surveys were undertaken to reveal the population dynamics of house dust mites, Dermatophagoides spp., in floor dusts collected from living rooms and bedrooms of 10 homes in and around Nagoya City, at about 3 month intervals from September 1983 to June 1985. All homes were more or less infested with both species of $D$. farinae (D. $f$.) and $D$. pteronyssinus (D. p.). Mean population density of $D . f$. exhibited seasonal fluctuation with the highest number in Sep. tember or June and the lowest in March in most of these homes, irrespective of room types and floor materials. The population structure of $D . f$. changed by season; relative increase of nymphs in winter populations was characteristic, sug. gesting the appearance of some desiccation-tolerant nymphs. On the contrary, seasonal fluctuation of $D$. p populations varied from home to home according to the types of rooms and floor materials. Relatively large numbers of $D . p$. were found in December or March in some 
homes. No marked difference was seen in the population structure of $D \cdot p$. between summer and winter populations. It was noted that the population density and structure of $D$. $p$. were almost constant in bedrooms with tatami floors. D. $p$. had a tendency to dominate in homes with fewer rooms to the family size. From these results, it was concluded that the population dynamics of $D$. $f$. and $D . p$. differed to some degree, although they have similar ecological niche. The difference seemed to be due mainly to the appearance of diapause nymphs in winter populations of $D$. $f$., but not in $D . p$. populations. 